\title{
Skuteczna terapia lewosimendanem u chorego z zaostrzeniem przewlekłej niewydolności serca z obniżoną frakcją wyrzutową lewej komory
}

\author{
Effective levosimendan therapy in patient with exacerbation \\ of chronic heart failure with reduced left ventricular ejection fraction
}

\author{
Kamil Janikowski, Małgorzata Lelonek \\ Zakład Kardiologii Nieinwazyjnej Uniwersytetu Medycznego w Łodzi
}

\section{Streszczenie}

Mężczyzna w wieku 62 lat został przyjęty z powodu zaostrzenia objawów przewlekłej niewydolności serca do IV klasy według New York Heart Association. Mimo zastosowania standardowej farmakoterapii ostrej niewydolności serca u chorego doszło do objawów hipoperfuzji narządowej z następczą oligurią, do bezmoczu włącznie. Pacjent został zakwalifikowany do leczenia lewosimendanem, dzięki czemu w kolejnych dobach uzyskano stabilizację stanu klinicznego chorego. $\mathrm{Na}$ podstawie przypadku klinicznego $\mathrm{w}$ artykule przedstawiono aktualny stan wiedzy na temat zastosowania lewosimendanu w ostrej niewydolności serca.

Słowa kluczowe: ostra niewydolność serca, farmakoterapia, lewosimendan

Folia Cardiologica 2017; 12, 4: 378-385

\section{Wstęp}

Zgodnie z wytycznymi Europejskiego Towarzystwa Kardiologicznego (ESC, European Society of Cardiology) [1] dotyczącymi diagnostyki i leczenia niewydolności serca (HF, heart failure) ostrą niewydolność serca (AHF, acute heart failure) definiuje się jako stan gwałtownie pojawiających się lub nasilających objawów, tj. duszności, orthopnoe, pogorszenia tolerancji wysiłku, retencji płynów pod postacią zastoju nad polami płucnymi, objawu wątrobowo-szyjnego, obrzęków obwodowych itp. Wyróżnia się AHF de novo, jeśli epizod występuje po raz pierwszy, oraz ostrą dekompensacje przewlekłej niewydolności serca (ADHF, acute decompensated heart failure), która obserwuje się u chorych z wcześniej rozpoznaną HF.

Dekompensacja przewlekłej niewydolności serca jest dominującą przyczyną hospitalizacji z powodu HF (80\% przyjęć do szpitali z powodu HF) [2]. Udokumentowano, że każde kolejne zaostrzenie choroby pogarsza rokowanie chorego, a długość hospitalizacji jest wprost proporcjonalna do ryzyka zgonu [3]. W ADHF śmiertelność wewnątrzszpitalna pozostaje wysoka; wśród chorych ze wstrząsem kardiogennym wynosi ona $40-60 \%$, natomiast u pozostałych chorych - poniżej $10 \%$ [4].

Przydatną w codziennej praktyce klinicznej i mocno zaznaczoną w obecnie obowiązujących wytycznych dotyczących AHF jest klasyfikacja kliniczna Forrestera, w której ocenia się obecność zastoju i/lub hipoperfuzji obwodowej. Ma to istotne znaczenie nie tylko przy doborze odpowiedniej farmakoterapii, ale również niesie za sobą praktyczne wartości prognostyczne.

Mimo obserwowanego postępu farmakoterapii HF, w przypadku manifestacji AHF od wielu lat są stosowane wciąż te same leki, w odniesieniu do których nie udowod-

Adres do korespondencji: prof. dr hab. n. med. Małgorzata Lelonek, FESC, Zakład Kardiologii Nieinwazyjnej, Uniwersytet Medyczny w Łodzi, ul. Żeromskiego 113, 90-549 Łódź, e-mail: malgorzata.lelonek@umed.lodz.pl 
niono wpływu na rokowanie chorych. W codziennej praktyce klinicznej zaleca się stosowanie dożylnych diuretyków pętlowych w celu zmniejszenia przewodnienia (klasa zaleceń I, poziom wiarygodności danych $\mathrm{C}$ ), leki wazodylatacyjne, aby ograniczyć objawy AHF (klasa zaleceń Ila, poziom wiarygodności danych $\mathrm{C}$ ) oraz leki inotropowe, by zwiększyć rzut serca, a co za tym idzie - ciśnienie tętnicze, znieść hipoperfuzję obwodową oraz utrzymać funkcje poszczególnych narządów (klasa zaleceń Ilb, poziom wiarygodności danych C). W przypadku pacjenta we wstrząsie kardiogennym eksperci ESC zalecają zastosowanie leków obkurczających naczynia (preferowana jest noradrenalina), wspomagająco dodanych do terapii lekami inotropowymi (klasa zaleceń Ilb, poziom wiarygodności danych B).

W opublikowanej w 2012 roku metaanalizie przeprowadzonej przez Landoni i wsp. [5] wykazano, że spośród wszystkich leków inotropowych jedynie zastosowanie lewosimendanu w porównaniu z placebo istotnie obniżyło śmiertelność pacjentów leczonych z przyczyn kardiologicznych. Lek ten został umieszczony w ostatnich wytycznych ESC (klasa zaleceń Ilb, poziom wiarygodności danych C) [1].

Poniżej przedstawiono przypadek pacjenta z zaostrzeniem przewlekłej HF, u którego zastosowano dożylny wlew lewosimendanu.

\section{Opis przypadku}

Mężczyzna w wieku 62 lat został przyjęty z powodu ADHF z dusznością spoczynkową w IV klasie niewydolności według New York Heart Association (NYHA), z narastającymi obrzękami kończyn dolnych od około miesiąca. W wywiadzie u chorego stwierdzono:

- przewlekłą HF z pośrednią frakcją wyrzutową (EF, ejection fraction) lewej komory (45\%);

- stan po operacyjnym leczeniu tętniaka rozwarstwiającego aorty typu I de Bakey (1999 r.);

- stan po implantacji sztucznej zastawki aortalnej Medtronic ATS 27, z jednoczasową plastyką zastawki trójdzielnej i zeszyciu przetrwałego otworu owalnego (2013 r.);

- brak istotnych zmian miażdżycowych w tętnicach wieńcowych w badaniu koronarograficznym;

- umiarkowaną niedomykalność mitralną (mechanizm I i IIlb wg Carpentiera);

- utrwalone migotanie przedsionków;

- nadciśnienie tętnicze;

- cukrzyce typu 2;

- dyslipidemię;

- blok prawej odnogi pęczka Hisa (RBBB, right bundle branch block);

- stan po endoprotezoplastyce obu stawów biodrowych (2014 r., 09/2016 r.);

- otyłość (wskaźnik masy ciała [BMI, body mass index] $\left.37,86 \mathrm{~kg} / \mathrm{m}^{2}\right)$.
Tabela 1. Klasyfikacja kliniczna według Forrestera i ryzyko zgonu w porównaniu z profilem „ciepły suchy” (zmodyfikowano wg [6])

$\begin{array}{ll}\text { "Ciepły suchy" } & \text { "Ciepły mokry" } \\ \text { Ryzyko względne 1,0 } & \text { Ryzyko względne 2,1 } \\ \text { "Zimny suchy” } & \text { "Zimny mokry" } \\ \text { Ryzyko względne 1,98 } & \text { Ryzyko względne 3,66 }\end{array}$

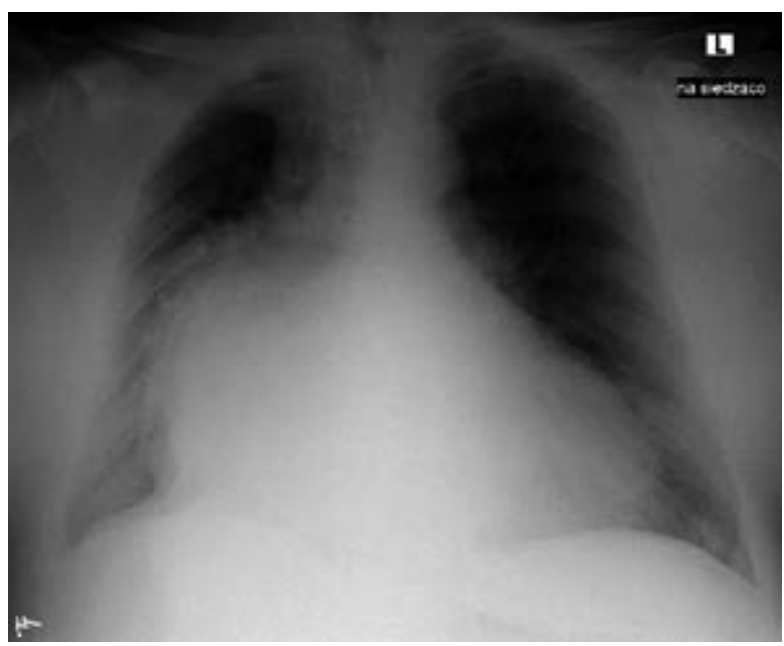

Rycina 1. Badanie radiologiczne klatki piersiowej pacjenta $w$ dniu przyjęcia do szpitala

Przy przyjęciu czynność serca chorego była niemiarowa, o częstości około 65/min, ciśnienie tętnicze wynosiło 95/60 mm Hg i zwracały uwagę cechy zastoju nad polami płucnymi ze ściszeniem szmeru u podstawy prawego płuca oraz masywne obrzęki obu podudzi. W klasyfikacji AHF według Forrestera chory był „ciepły i mokry” (tab. 1). W wykonanym badaniu radiologicznym (RTG) klatki piersiowej (ryc. 1) opisano masywnie powiększoną sylwetkę mięśnia sercowego oraz cechy niewydolności w krążeniu płucnym. W spoczynkowym zapisie elektrokardiograficznym (EKG) zarejestrowano migotanie przedsionków z częstością zespołów QRS 45-60/min, okresową bigeminię komorową oraz blok prawej odnogi pęczka Hisa. Wyniki badań laboratoryjnych przedstawiono w tabeli 2.

W badaniach echokardiograficznych, przezklatkowym i przezprzełykowym, zobrazowano prawidłowo funkcjonującą sztuczną zastawkę aortalną, dobry efekt plastyki zastawki trójdzielnej z użyciem pierścienia oraz umiarkowaną niedomykalność zastawki mitralnej (typ I i IIlb wg Carpentiera). Opisano ciężką dysfunkcję skurczową powiększonej, kulistej lewej komory (wymiary 79/59 mm, EF 28\%) z uogólnioną hipokinezą ścian oraz olbrzymi lewy przedsionek (objętość $439 \mathrm{ml}$ ). W jamach serca nie uwidoczniono skrzeplin.

W diagnostyce różnicowej uwzględniono przedstawiony wnajnowszych wytycznych schematpostępowania oakronimie 
Tabela 2. Wyniki badań laboratoryjnych przy przyjęciu pacjenta do szpitala

\begin{tabular}{|c|c|c|}
\hline Parametr & Wartość & Zakres normy \\
\hline Stężenie hemoglobiny [g/dl] & 12,1 & $14,0-18,0$ \\
\hline Liczba erytrocytów $\left[\times 10^{6} / \mu \mathrm{l}\right]$ & 3,98 & $4,20-6,10$ \\
\hline Wartość hematokrytu (\%) & 38,1 & $40,0-55,0$ \\
\hline Liczba leukocytów $\left[\times 10^{6} / \mu l\right]$ & 5,40 & $4,00-11,00$ \\
\hline Liczba płytek krwi $\left[\times 10^{6} / \mu l\right]$ & 217 & $150-400$ \\
\hline Wartość INR & 1,87 & $0,8-1,2$ \\
\hline Stężenie kreatyniny $[\mu \mathrm{mol} / \mathrm{I}]$ & 85,0 & $59,0-104,0$ \\
\hline Wartość GFR [ml/min/1,73 m²] & 87,1 & $>60,0$ \\
\hline Stężenie glukozy [mmol/l] & 6,89 & $4,1-5,5$ \\
\hline Stężenie CRP [mg/l] & 11,1 & $0,0-6,0$ \\
\hline Stężenie NT-proBNP [pg/ml] & $5463,0 \rightarrow 5167,0 *$ & $<125,0$ \\
\hline Stężenie troponiny T oznaczonej metodą wysokoczułą [ng/l] & $38 \rightarrow>35^{*}$ & $<14$ \\
\hline
\end{tabular}

*Oznaczenie wykonane w 3. dobie hospitalizacji; INR (international normalized ratio) - międzynarodowy współczynnik znormalizowany; GFR (glomerular filtration rate) - współczynnik filtracji kłębuszkowej; CRP (C-reactive protein) - białko C-reaktywne; NT-proBNP (N-terminal B-type natriuretic propeptide) - N-końcowy fragment propetydu natriuretyczngo typu B

CHAMP, który ma za zadanie pomóc lekarzom w szybkiej identyfikacji i leczeniu czynników wyzwalających AHF:

- C-acute coronary syndrome (ostry zespół wieńcowy);

- $\mathbf{H}$-hypertension (przełom nadciśnieniowy);

- A - arrhythmia (zaburzenia rytmu);

- M - acute mechanical cause (ostra mechaniczna przyczyna AHF);

- P - pulmonary embolism (zatorowość płucna).

Ze względu na pośrednie prawdopodobieństwo ostrej zatorowości płucnej (3 pkt. wg skali Wellsa) oraz dodatni wynik oznaczenia D-dimeru (1,16 mg/l, norma < 0,5 mg/l) wykonano badanie angiograficzne tomografii komputerowej (angio-CT, computed tomography angiography) tętnic płucnych, w którym nie uwidoczniono ubytków zakontrastowania. Dodatkowo w badaniu ultrasonograficznym żył kończyn dolnych metodą Dopplera również nie zarejestrowano materiału zakrzepowo-zatorowego. Biorąc pod uwagę całość obrazu klinicznego, rozpoznano zaostrzenie przewlekłej niewydolności serca z obniżoną frakcją wyrzutową lewej komory (HFrEF, heart failure with reduced ejection fraction) i zastosowano pełne leczenie HF, w tym intensywne dożylne leczenie lekami moczopędnymi (furosemid, torasemid) oraz dopaminą w przepływie $3 \mathrm{ml} / \mathrm{h}$, początkowo z dobrą reakcją diuretyczną pacjenta. Ze względu na nieterapeutyczny poziom międzynarodowego wskaźnika znormalizowanego (INR, international normalized ratio) włączono parenteralne leczenie antykoagulacyjne.

W 3. dobie nie udokumentowano istotnego obniżenia wartości N-końcowego fragmentu propetydu natriuretyczngo typu B (NT-proBNP, N-terminal B-type natriuretic propeptide) względem wartości oznaczonej przy przyjęciu do szpitala (5463 pg/ml $\rightarrow 5167 \mathrm{pg} / \mathrm{ml}$ ). W 4. i 5. dobie rejestrowano brak istotnej poprawy klinicznej mimo za- stosowanego typowego leczenia, ze stopniowym zmniejszaniem ilości oddawanego moczu (ryc. 2), do bezmoczu włącznie (klasyfikację wg Forrestera u chorego zmieniono na „zimny i mokry” - strzałka w tab. 1 wskazuje zmianę profilu hemodynamicznego oraz wzrost ryzyka względnego zgonu chorego do 3,66 w porównaniu z pacjentem o profilu „ciepły i suchy”).

Ciśnienie pacjenta wynosiło wówczas 110/60 mm Hg, w związku z czym został zakwalifikowany do leczenia lewosimendanem (przepływ $13 \mathrm{ml}$ przez $24 \mathrm{~h}$ ), bez podania wstępnego bolusa. W kolejnych dobach intensywnej terapii obserwowano dobrą tolerancję leku przez chorego, stopniową poprawę stanu klinicznego, w tym ustąpienie duszności spoczynkowej, zmniejszenie obrzęków obwodowych oraz zwiększenie diurezy (ryc. 2). Nie zarejestrowano istotnych zmian wartości współczynnika filtracji kłębuszkowej (GFR, glomerular filtration rate). Kontynuowano klasyczne leczenie HF zgodnie z wytycznymi ESC do pełnego ustabilizowania stanu chorego.

W teście 6-minutowego marszu pacjent przebył dystans 188 m, z nasileniem duszności z 3 do 7 punktów w skali Borga. Ze względu na obserwowaną od przyjęcia w spoczynkowym zapisie EKG pojedynczą ekstrasystolię komorową wykonano 24-godzinne monitorowanie EKG metodą Holtera. Zarejestrowano różnoośrodkową arytmię komorową do 40 tys. pobudzeń/dobę (38 tys. z jednego ośrodka, do 2100/h, w tym 1600 okresów bigeminii komorowej o czasie trwania do 10 min 25 s, 1000 par ExV) oraz wolny częstoskurcz komorowy (slowVT, slow ventricular tachycardia)/nieutrwalony częstoskurcz komorowy (nsVT, nonsustained ventricular tachycardia) o częstości 70-174/ /min (2 epizody o częstości 146-156/min składające się z 9-15 pobudzeń). Włączono amiodaron, uzyskując ogra- 


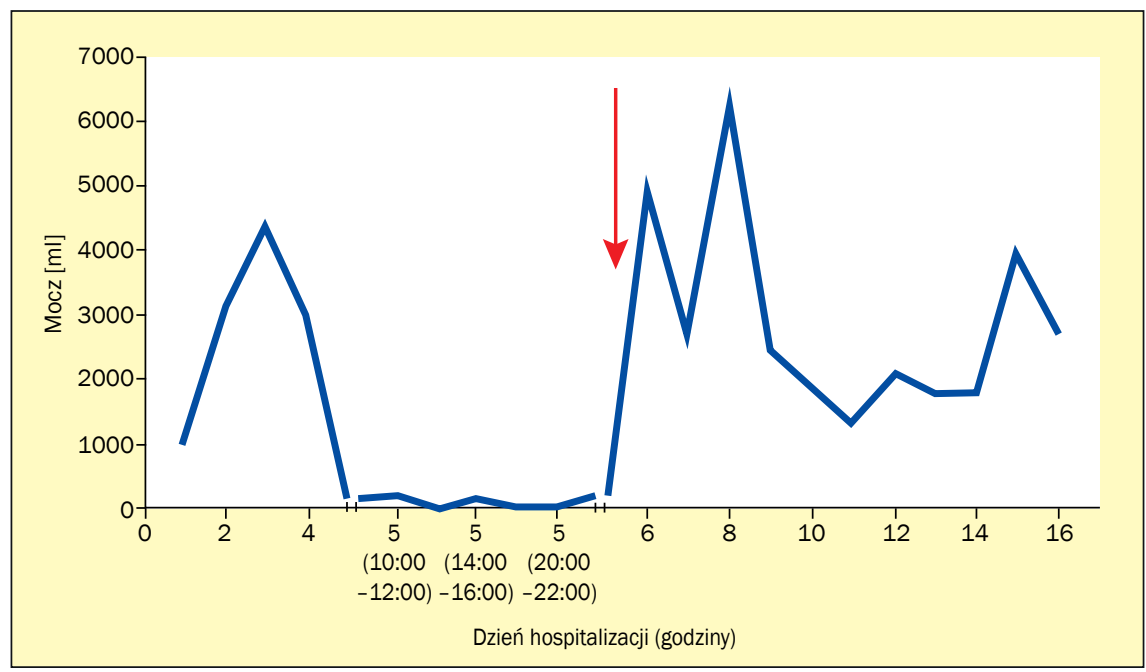

Rycina 2. Diureza pacjenta w czasie hospitalizacji - strzałką wskazano dzień dożylnego podania lewosimendanu

Tabela 3. Farmakoterapia pacjenta przy wypisaniu ze szpitala

\begin{tabular}{lc}
\hline Lek i dawka & Schemat stosowania \\
\hline Acenocumarol $4 \mathrm{mg}$ & Zależnie od wartości INR \\
Winian metoprololu $50 \mathrm{mg}$ & $1 / 2-0-1 / 2$ tabl. \\
Amiodaron $200 \mathrm{mg}$ & $1-0-0$ tabl. \\
Ramipril $2,5 \mathrm{mg}$ & $0-0-1$ tabl. \\
Furosemid $40 \mathrm{mg}$ & $2-0-0$ tabl. \\
Torasemid $20 \mathrm{mg}$ & $0-1-0$ tabl. \\
Hydrochlorotiazyd $25 \mathrm{mg}$ & $1 / 2-0-0$ tabl. \\
Spironolakton $25 \mathrm{mg}$ & $0-1-0$ tabl. \\
Rosuwastatyna $20 \mathrm{mg}$ & $0-0-1$ tabl. \\
Allopurinol $100 \mathrm{mg}$ & $1-0-0$ tabl. \\
Metformina $850 \mathrm{mg}$ & $1-1-0$ tabl. \\
Metformina $1000 \mathrm{mg}$ & $0-0-1$ tabl. \\
Gliklazyd $30 \mathrm{mg}$ & $1-0-0$ tabl.
\end{tabular}

niczenie arytmii. Zalecono wykonanie kontrolnego badania holterowskiego po wypisaniu ze szpitala.

Po 17 dniach hospitalizacji pacjenta w stabilnej II/III klasie niewydolności według NYHA wypisano do domu, z zaleceniem dalszej opieki kardiologicznej w warunkach ambulatoryjnych oraz wykonania kontrolnej oceny w badaniu EKG metodą Holtera. Zaleconą farmakoterapię podano w tabeli 3.

Po miesiącu pacjent zgłosił się na poszpitalną wizytę kontrolną do poradni kardiologicznej. Chory był w III klasie niewydolności według NYHA; ciśnienie tętnicze wynosiło 125/75 mm Hg. Osłuchowo nad polami płucnymi nie zanotowano cech zastoju, pozostał ślad obrzęków wokół kostek kończyn dolnych. W spoczynkowym zapisie EKG zarejestro- wano migotanie przedsionków z częstością rytmu komór około 85/min. z pojedynczymi ExV i RBBB oraz czasem trwania zespołu QRS 125 ms. W kontrolnym badaniu EKG metodą Holtera udokumentowano redukcję ExV do 5000/ /dobę, bez form złożonych. Utrzymano dotychczasowe leczenie. Zaplanowano elektroterapię po kolejnych 2 miesiącach optymalnej farmakoterapii (OMT, optimal medical therapy).

\section{Omówienie}

Ze względu na poważne rokowanie pacjentów z AHF zasadnym jest ciągłe poszukiwanie nowoczesnych form farmakoterapii pacjentów z różnymi fenotypami tej choroby. W opublikowanych w ostatnim roku wynikach badań klinicznych dotyczących dwóch leków, z którymi środowisko kardiologiczne wiązało duże nadzieje - serelaksyny (RELAX-AHF-2, Efficacy, Safety and Tolerability of Serelaxin When Added to Standard Therapy in AHF) i ularytydu (TRUE-AHF, TRial of Ularitide's Efficacy and safety in patients with Acute Heart Failure) - nie wykazano istotnego wpływu zastosowania tych cząsteczek na długoterminowe rokowanie w populacji z AHF. W wytycznych ESC dopuszcza się zastosowanie lewosimendanu w tej grupie chorych (klasa zaleceń Ilb, poziom wiarygodności danych C). Lek ten został po raz pierwszy dopuszczony do obrotu w Szwecji w 2000 roku; obecnie jest dostępny w ponad 50 krajach na świecie. W tabeli 4 przedstawiono wyniki badań klinicznych dotyczących zastosowania lewosimendanu w grupie chorych z AHF.

Zwraca uwagę fakt, że w dwóch badaniach klinicznych z zastosowaniem lewosimendanu udokumentowano poprawę rokowania pacjentów z AHF. Do badania LIDO (Levosimendan Infusion versus Dobutamine) włączono 203 pacjentów z HFrEF o etiologii niedokrwiennej lub nieniedokrwiennej wymagających cewnikowania prawej części serca oraz dożylnego podawania leków inotropowych. 
Tabela 4. Badania kliniczne dotyczące lewosimendanu (zmodyfikowano wg [7])

\begin{tabular}{|c|c|c|c|c|c|}
\hline $\begin{array}{l}\text { Akronim ba- } \\
\text { dania }\end{array}$ & $\begin{array}{l}\text { Liczba włączonych } \\
\text { pacjentów }\end{array}$ & Kryterium włączenia & Komparator & $\begin{array}{l}\text { Pierwszorzędowy } \\
\text { punkt końcowy }\end{array}$ & $\begin{array}{l}\text { Poprawa } \\
\text { rokowania }\end{array}$ \\
\hline LIDO & 203 & III/IV klasa HF wg NYHA & Dobutamina & $\begin{array}{l}\text { Ocena parametrów hemodyna- } \\
\text { micznych metodą inwazyjną }\end{array}$ & Tak \\
\hline RUSSLAN & 203 & $\begin{array}{l}\text { IV klasa HF wg NYHA } \\
\text { po MI }\end{array}$ & Placebo & Bezpieczeństwo & Tak \\
\hline REVIVE I & 100 & IV klasa HF wg NYHA & Placebo & Klinicznie złożony* & $\mathrm{Nie}$ \\
\hline REVIVE II & 600 & IV klasa HF wg NYHA & Placebo & Klinicznie złożony* & $\mathrm{Nie}$ \\
\hline SURVIVE & 1327 & IV klasa HF wg NYHA & Dobutamina & Śmiertelność & $\mathrm{Nie}$ \\
\hline
\end{tabular}

*Klinicznie złożony punkt końcowy składał się z subiektywnej oceny objawów pacjentów biorących udział w badaniu w kilku punktach czasowych (po 6 i 24 godzinach i po 5 dniach) oraz cech pogorszenia (w tym zgonu) w ciagu 5 dni od rozpoczęcia wlewu leku; LIDO - Levosimendan Infusion versus Dobutamine; HF (heart failure) - niewydolność serca; NYHA - New York Heart Association; RUSSLAN - Randomised stUdy on Safety and effectivenesS of Levosimendan in patients with left ventricular failure due to an Acute myocardial iNfarct; MI (myocardial infarction) - zawał serca; REVIVE - Randomized Multicenter Evaluation of Intravenous Levosimendan Efficacy; SURVIVE - Design, Setting, and Patients The Survival of Patients With Acute Heart Failure in Need of Intravenous Inotropic Support

Komparatorem lewosimendanu była dobutamina. Przeprowadzona analiza wykazała, że w obserwacji 180-dniowej lewosimendan istotnie zmniejszał śmiertelność chorych (26\% v. 38\%, współczynnik ryzyka [HR, hazard ratio] 0,57; 95-proc. przedział ufności [Cl, confidence interval] 0,34-0,95]; $p=0,029$ ) [8]. Z kolei w wynikach badania RUSSLAN zaprezentowano istotną statystycznie redukcję śmiertelności w 14. dniu od rozpoczęcia leczenia (lewosimendan v. placebo). Po 6 miesiącach obserwacji uzyskano trend korzystny dla badanego leku $(22,6 \%$ v. 31,4\%; HR 0,67; 95\% Cl 0,45-1,00; $p=0,053$ ) [9].

Ciekawych danych dostarczyły również wyniki badania ALARM-HF (Acute Heart Failure Global Survey of Standard Treatment), w którym porównywano śmiertelność wewnątrzszpitalną pacjentów leczonych w monoterapii dożylnym lekiem inotropowym (w tym lewosimendanem) lub katecholaminą (adrenalina, noradrenalina). Udowodniono wyższość terapii lewosimendanem nad pozostałymi lekami badanymi w tym projekcie [10].

Warto również wspomnieć o opublikowanej w 2016 roku pracy Pollesello i wsp. [11], w której zbiorczo przeanalizowano wyniki przedstawionych w ostatnich latach metaanaliz, na które składało się łącznie 58 publikacji. Wśród pięciu cytowanych prac dotyczących populacji chorych z AHF wykazano zmniejszenie śmiertelności dzięki zastosowaniu lewosimendanu [12-16]. Należy zaznaczyć, że Ribeiro i wsp. [14] nie uzyskali istotności statystycznej przedstawionych wyliczeń, porównując śmiertelność w grupie otrzymującej lewosimendan oraz przyjmującej placebo czy dobutamine. Delaney i wsp. [15] natomiast uzyskali istotne ograniczenie śmiertelności, porównując zastosowanie badanego leku z dobutaminą, lecz nie w porównaniu z placebo.

Udowodniona poprawa rokowania po zastosowaniu lewosimendanu wśród chorych z AHF przekłada się na korzystne analizy farmakoekonomiczne. Fedele i wsp. [17] wykazali, że chorzy leczeni tym lekiem byli hospitalizowani średnio o 1,5 dnia krócej niż pacjenci z grupy kontrolnej $(p<0,05)$, rzadziej raportowano $u$ nich rehospitalizacje $(\mathrm{p}<0,05)$ i charakteryzowali się istotnie niższym wskaźnikiem śmiertelności po miesiącu obserwacji $(2,1$ v. 6,9\%; $p<0,05)$. Koszt leczenia chorego lewosimendanem podczas pierwszego pobytu w szpitalu był o 79 euro wyższy niż koszt terapii bez użycia tego leku, jednak - biorąc pod uwage ponowne hospitalizacje - udowodniono, że całkowity koszt leczenia chorego z zastosowaniem lewosimendanu był o 280 euro niższy niż koszt terapii z pominięciem tej substancji.

\section{Wielokierunkowy mechanizm działania lewosimendanu}

Lewosimendan ulega w głównej mierze sprzęganiu z glutationem, dzięki czemu powstają jego nieaktywne metabolity. Ponadto 6\% podanego leku jest redukowane w jelitach do pośredniego metabolitu - OR-1855, który w następnych etapach podlega acetylacji do aktywnej cząsteczki - OR-1896. Co ciekawe, substancja OR-1896 cechuje się podobnym działaniem hemodynamicznym i farmakologicznym, co lek w pierwotnej formie. Jej okres półtrwania jest znacznie dłuższy niż lewosimendanu (ok. 80 h v. 1 h), dzięki czemu po wydaleniu leku z moczem i kałem w organizmie człowieka utrzymuje się jego efekt leczniczy przez co najmniej 7 dni, co wpływa korzystnie na profil hemodynamiczny, neurohormonalny i stan kliniczny chorego (tab. 5).

Lewosimendan jest lekiem charakteryzującym się potrójnym mechanizmem działania. Cząsteczka tej substancji wiąże się wybiórczo z troponiną C, która łączy się z jonami wapnia, przez co zwiększa wrażliwość komórki mięśnia sercowego na ten pierwiastek i skutkuje wzrostem kurczliwości kardiomiocytów. Należy podkreślić, że jednocześnie nie obserwuje się wpływu na rytm serca ani właściwości elektrofizjologiczne komórek mięśnia sercowego. Dzięki temu lek może być zastosowany jako terapia pomostowa (bridge therapy) u chorych z najcięższymi postaciami HF, oczekujących na transplantacje serca czy wszczepienie urządzenia wspomagającego pracę lewej komory serca. Z kolei za działanie wazodylatacyjne odpowiada wpływ lewosimendanu na otwarcie ATP-zależnych kanałów po- 
Tabela 5. Efekty stosowania lewosimendanu (zmodyfikowano wg [7])

\author{
Efekty hemodynamiczne i neurohormonalne \\ Obniżenie ciśnienia zaklinowania w kapilarach płucnych \\ Wzrost pojemności minutowej \\ Wzrost pojemności wyrzutowej \\ Spadek systemowego oporu naczyniowego \\ Spadek naczyniowego oporu płucnego \\ Obniżenie stężenia peptydów natriuretycznych
}

\section{Pozostałe efekty kliniczne}

Zmniejszenie objawów niewydolności serca

Trwałość efektu również podczas równoległego stosowania leku beta-adrenolitycznego

Trwałość efektu dzięki aktywnym metabolitom leku

Brak zjawiska tachyfilaksji

Brak wzrostu poziomu zużycia tlenu przez mięsień sercowy

Zapobieganie niedokrwieniu mięśnia sercowego

Brak upośledzenia funkcji rozkurczowej mięśnia sercowego

tasowych miocytów i rozszerzenie naczyń krwionośnych oraz poprawę krążenia w tętnicach wieńcowych, co skutkuje większą podażą tlenu. Jest to istotne w przypadku leczenia chorego z AHF ze współistniejącym zespołem sercowo-nerkowym, szczególnie jeśli w obrazie klinicznym występuje zmniejszony rzut serca z hipoperfuzją nerek (typy 1 i 2) [18]. W jeszcze innej sytuacji - niedokrwienia mięśnia sercowego - lewosimendan wykazuje właściwości kardioprotekcyjne poprzez otwarcie ATP-zależnych kanałów potasowych w mitochondriach komórek mięśnia sercowego. Znajduje to swoje uzasadnienie w zastosowaniu tego leku u chorych z zawałem serca poddawanym przezskórnym interwencjom wieńcowym lub bezpośredniej rewaskularyzacji mięśnia sercowego.

\section{Wpływ lewosimendanu na pracę nerek i wątroby}

Udowodniono, że lewosimendan poprawia funkcje nerek dwutorowo. Po pierwsze, poprawia krążenie nerkowe poprzez korzystny wpływu na hemodynamikę mięśnia sercowego. Po drugie, Bragadottir i wsp. [19] wykazali w swoich badaniach, że lek ten poprawia perfuzję nerek i wzrost GFR dzięki poszerzeniu tętniczki doprowadzającej.

W badaniu SURVIVE [20] porównywano między innymi wpływ lewosimendanu i dobutaminy na dynamikę poziomu aktywności aminotransferaz wątrobowych. Istotną statystycznie różnicę w zakresie obniżenia wartości tych markerów na korzyść lewosimendanu zarejestrowano już w obserwacji kilkudniowej od rozpoczęcia wlewu badanych leków $(p<0,012)$.

Zgodnie z licznymi doniesieniami naukowymi, dzięki plejotropowemu działaniu lewosimendanu, korzyści z terapii tym lekiem mogą odnieść chorzy w różnych stanach klinicznych (tab. 6).

\section{Praktyczne wskazówki dotyczące zastosowania lewosimendanu}

Według informacji zawartych w charakterystyce produktu leczniczego lewosimendanu (preparat Simdax ${ }^{\circledR}$ ) [22] lek ten jest przeznaczony do krótkotrwałego leczenia ADHF
Tabela 6. Stany kliniczne, w których odnotowano korzystne zastosowanie lewosimendanu (źródło [21])

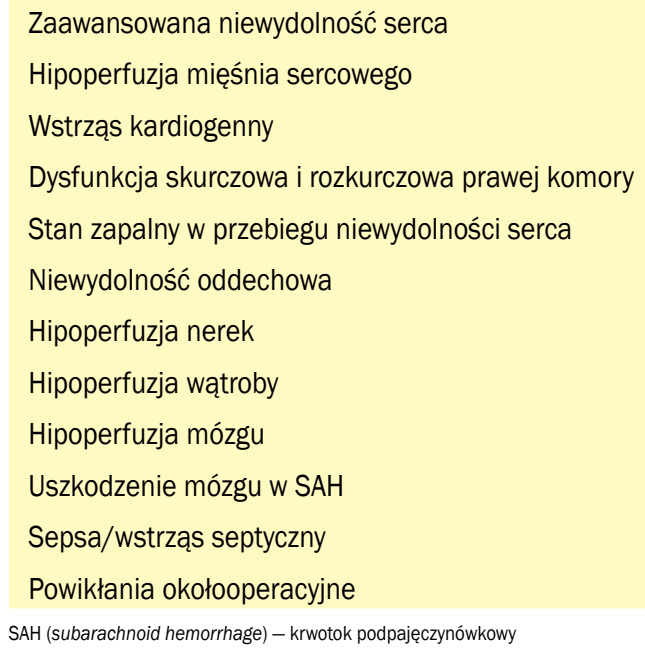

w sytuacjach, gdy nie obserwuje się poprawy stanu klinicznego chorego poddanego zaleconemu leczeniu HF oraz gdy istnieje konieczność zastosowania leków o działaniu inotropowo dodatnim. Z praktycznego punktu widzenia istotne jest wczesne podanie lewosimendanu choremu - tak jak w zaprezentowanym przypadku, gdy jeszcze nie doszło do istotnego spadku GFR, mimo objawów hipoperfuzji nerkowej. W dotyczących HF wytycznych ESC z 2016 roku przewidziano zastosowanie tego leku w celu odwrócenia działania stosowanych standardowo przez pacjentów leków beta-adrenolitycznych w przypadku podejrzenia, że przyczyną dekompensacji chorego jest stosowanie leków z tej grupy, z następczą hipotonią i hipoperfuzją narządową (klasa zaleceń IIb, poziom wiarygodności danych C). Co ciekawe, w ostatnich wytycznych Amarican College of Cardiology (ACC)/American Heart Association (AHA) z 2017 roku dotyczących HF nie zawarto informacji o tym leku [23].

Zgodnie z obowiązującym stanem wiedzy optymalnym kandydatem do leczenia lewosimendanem jest pacjent charakteryzujący się następującymi cechami: 
- ADHF z objawami obniżonej perfuzji narządowej;

- brakiem istotnej hipotonii i zaburzeń rytmu serca (tachykardia oraz torsades de pointes w wywiadzie);

- HFrEF z EF lewej komory poniżej 40\%;

- dotychczas poddany OMT (leki moczopędne, leki beta-adrenolityczne, inhibitory konwertazy angiotensyny [ACEl, angiotensin-converting enzyme inhibitors], antagoniści receptora dla angiotensyny [ARB, angiotensin receptor blockers], antagoniści receptora mineralokortykoidowego [MRA, mineralocorticoide receptor antagonists]).

Działanie substancji utrzymuje się przez co najmniej 24 godziny, natomiast metabolity mogą działać do 9 dni od zakończenia wlewu. Nie zaleca się stosowania dawki nasycającej leku; preferuje się wlew ciągły z prędkością 0,1 $\mathrm{mg} / \mathrm{kg}$ mc./min i możliwością jego zwiększenia do 0,2 $\mu \mathrm{g} / \mathrm{kg}$ mc./ /min. W trakcie podawania leku konieczne jest monitorowanie chorego (ciśnienie tętnicze, tętno). W przypadku obserwowania hipotonii i/lub tachykardii istnieje możliwość zmniejszenia przepływu do 0,05 $\mathrm{\mu g} / \mathrm{kg} \mathrm{mc}$./min. Zalecana obserwacja chorego w warunkach szpitalnych powinna trwać 4-5 dni. Warto podkreślić, że przed zastosowaniem lewosimendanu należy wyrównać zaburzenia elektrolitowe (głównie stężenie jonów potasu), aby zminimalizować ryzyko wystąpienia arytmii oraz unikać nadmiernego odwonienia chorego.

Dla pacjentów z ciężką AHF, charakteryzujących się niskim rzutem serca oraz hipotonią, którzy zostali zdyskwalifikowani z transplantacji serca lub zastosowania urządzeń do mechanicznego wspomagania lewej komory (LVAD, left ventricular assist device), opcją terapeutyczną może być zastosowanie powtarzalnych wlewów (repetitive use) z lewosimendanu. Delgado i wsp. [24] zalecają zastosowanie takiej terapii co 2-4 tygodnie. Najdłużej poddawanym takiej terapii był chory z zespołem niedorozwoju lewego serca (HLHS, hypoplastic left heart syndrome), który otrzymał 105 cykli leku przed transplantacją serca [24].
Lewosimendanu nie zaleca się u pacjentów z hipotonią, istotną tachykardią, w przewlekłej chorobie nerek z GFR poniżej $30 \mathrm{ml} / \mathrm{min}$, w ciężkich zaburzeniach pracy wątroby czy z komorowymi zaburzeniami rytmu serca typu torsades de pointes w wywiadzie. Nie ma konieczności zmniejszenia dawki u osób starszych. Według dostępnych informacji na temat tego leku nie obserwowano zjawiska tachyfilaksji [25]. Do najczęstszych działań niepożądanych lewosimendanu należą:

- hipotonia;

- tachykardia;

- zaburzenia rymu serca (migotanie przedsionków, dodatkowe skurcze komorowe, częstoskurcz komorowy);

- bóle i zawroty głowy;

- bezsenność;

- hipokaliemia;

- nudności, wymioty, zaparcia, biegunki.

\section{Podsumowanie}

W niniejszej pracy przedstawiono skuteczną terapię lewosimendanem pacjenta z ADHF w przebiegu HFrEF, u którego mimo standardowej farmakoterapii doszło do objawów hipoperfuzji narządowej, z następczą oligurią, do bezmoczu włącznie. W AHF należy pamiętać o różnych fenotypach klinicznych i konieczności stosowania indywidualnej terapii.

Mamy nadzieję, że ze wzglądu na coraz większą liczbę danych klinicznych potwierdzających pozytywny i wielokierunkowy wpływ lewosimendanu w AHF, w tym poprawe przeżycia chorych, lek ten uzyska lepszą pozycję w kolejnych uaktualnieniach wytycznych ESC dotyczących HF.

\section{Konflikt interesów}

Autorzy deklarują brak konfliktu interesów.

\section{Abstract}

A 62-year-old man was admitted due to exacerbation of chronic heart failure symptoms to IV New York Heart Association class. Despite the standard pharmacotherapy of acute heart failure, the patient developed symptoms of organ hypoperfusion, followed by oliguria and anuria. The patient was qualified for levosimendan treatment, resulting in stabilization of his clinical status in subsequent days. The study presents the current knowledge of levosimendan use in acute heart failure.

Key words: acute heart failure, pharmacotherapy, levosimendan

Folia Cardiologica 2017; 12, 4: 378-385 


\section{Piśmiennictwo}

1. Ponikowski P, Voors AA, Anker SD, et al. Authors/Task Force Members. 2016 ESC Guidelines for the diagnosis and treatment of acute and chronic heart failure: the Task Force for the diagnosis and treatment of acute and chronic heart failure of the European Society of Cardiology (ESC). Developed with the special contribution of the Heart Failure Association (HFA) of the ESC. Eur Heart J. 2016; 37(27): 2129-2200, doi: 10.1093/eurheartj/ehw128, indexed in Pubmed: 27206819.

2. Gheorghiade M, Pang PS. Acute heart failure syndromes. J Am Coll Cardiol. 2009; 53(7): 557-573, doi: 10.1016/j.jacc.2008.10.041, indexed in Pubmed: 19215829.

3. Solomon SD, Dobson J, Pocock S, et al. Candesartan in Heart failure: Assessment of Reduction in Mortality and morbidity (CHARM) Investigators. Influence of nonfatal hospitalization for heart failure on subsequent mortality in patients with chronic heart failure. Circulation. 2007; 116(13): 1482-1487, doi: 10.1161/CIRCULATIONAHA.107.696906, indexed in Pubmed: 17724259.

4. Nieminen MS, Brutsaert D, Dickstein K, et al. EuroHeart Failure Survey II (EHFS II): a survey on hospitalized acute heart failure patients: description of population. Eur Heart J. 2006; 27(22): 2725-2736, doi: 10.1093/eurheartj/ehl193, indexed in Pubmed: 17000631.

5. Landoni G, Biondi-Zoccai G, Greco M. Effects of levosimendan on mortality and hospitalization. A meta-analysis of randomized controlled studies. Crit Care Med. 2012; 40(2): 634-646, doi: 10.1097/ /CCM.0b013e318232962a, indexed in Pubmed: 21963578.

6. Rozentryt P. Zastój narządowy w niewydolności serca. Terapia. 2016; 9(2).

7. SIMDAX ${ }^{\circledR}$ monografia produktu. Orion Pharma 2015.

8. Follath F, Cleland JGF, Just $\mathrm{H}$, et al. Steering Committee and Investigators of the Levosimendan Infusion versus Dobutamine (LIDO) Study. Efficacy and safety of intravenous levosimendan compared with dobutamine in severe low-output heart failure (the LIDO study): a randomised double-blind trial. Lancet. 2002; 360(9328): 196-202, indexed in Pubmed: 12133653.

9. Moiseyev VS, Põder P, Andrejevs N, et al. RUSSLAN Study Investigators. Safety and efficacy of a novel calcium sensitizer, levosimendan, in patients with left ventricular failure due to an acute myocardial infarction. A randomized, placebo-controlled, double-blind study (RUSSLAN). Eur Heart J. 2002; 23(18): 1422-1432, indexed in Pubmed: 12208222.

10. Follath F, Yilmaz MB, Delgado JF, et al. Clinical presentation, management and outcomes in the Acute Heart Failure Global Survey of Standard Treatment (ALARM-HF). Intensive Care Med. 2011; 37(4): 619-626, doi: 10.1007/s00134-010-2113-0, indexed in Pubmed: 21210078.

11. Pollesello P, Parissis J, Kivikko M, et al. Levosimendan meta-analyses: is there a pattern in the effect on mortality? Int J Cardiol. 2016; 209: 77-83, doi: 10.1016/j.ijcard.2016.02.014, indexed in Pubmed: 26882190.

12. Cleland JGF, Ghosh J, Freemantle N, et al. Clinical trials update and cumulative meta-analyses from the American College of Cardiology: WATCH, SCD-HeFT, DINAMIT, CASINO, INSPIRE, STRATUS-US, RIO-Lipids and cardiac resynchronisation therapy in heart failure. Eur J Heart Fail. 2004; 6(4): 501-508, doi: 10.1016/j.ejheart.2004.04.014, indexed in Pubmed: 15182777.
13. Cleland JGF, Freemantle N, Coletta AP, et al. Clinical trials update from the American Heart Association: REPAIR-AMI, ASTAMI, JELIS, MEGA, REVIVE-II, SURVIVE, and PROACTIVE. Eur J Heart Fail. 2006; 8(1): 105-110, doi: 10.1016/j.ejheart.2005.12.003, indexed in Pubmed: 16387630.

14. Ribeiro RA, Rohde LE, Polanczyk CA. Levosimendan in acute decompensated heart failure: systematic review and meta-analysis. Arq Bras Cardiol. 2010; 95(2): 230-237, indexed in Pubmed: 20549133.

15. Delaney A, Bradford C, McCaffrey J, et al. Levosimendan for the treatment of acute severe heart failure: a meta-analysis of randomised controlled trials. Int J Cardiol. 2010; 138(3): 281-289, doi: 10.1016/j. ijcard.2008.08.020, indexed in Pubmed: 18817994.

16. Gong B, Li Z, Yat Wong PC. Levosimendan treatment for heart failure: a systematic review and meta-analysis. J Cardiothorac Vasc Anesth. 2015; 29(6): 1415-1425, doi: 10.1053/j.jvca.2015.03.023, indexed in Pubmed: 26275522.

17. Fedele F, D'Ambrosi A, Bruno N, et al. Cost-effectiveness of levosimendan in patients with acute heart failure. J Cardiovasc Pharmacol. 2011; 58(4): 363-366, doi: 10.1097/FJC.0b013e318224e0a2, indexed in Pubmed: 21697728.

18. Fedele F, Karason K, Matskeplishvili S. Pharmacological approaches to cardio-renal syndrome: a role for the inodilator levosimendan. Eur Heart J Suppl. 2017; 19(Suppl C): C22-C28, doi: 10.1093/eurheartj/ /sux002.

19. Bragadottir G, Redfors B, Ricksten SE. Effects of levosimendan on glomerular filtration rate, renal blood flow, and renal oxygenation after cardiac surgery with cardiopulmonary bypass: a randomized placebo-controlled study. Crit Care Med. 2013; 41(10): 23282335, doi: 10.1097/CCM.0b013e31828e946a, indexed in Pubmed: 23921271.

20. Farmakis D, Alvarez J, Gal TB, et al. Levosimendan beyond inotropy and acute heart failure: evidence of pleiotropic effects on the heart and other organs: An expert panel position paper. Int J Cardiol. 2016; 222: 303-312, doi: 10.1016/j.ijcard.2016.07.202, indexed in Pubmed: 27498374.

21. Nikolaou M, Parissis J, Yilmaz MB, et al. Liver function abnormalities, clinical profile, and outcome in acute decompensated heart failure. Eur Heart J. 2013; 34(10): 742-749, doi: 10.1093/eurheartj/ehs332, indexed in Pubmed: 23091203.

22. Simdax ${ }^{\circledR}$ - Charakterystyka Produktu Leczniczego.

23. Yancy CW, Jessup M, Bozkurt B, et al. 2017 ACC/AHA/HFSA focused 4pdate of the 2013 ACCF/AHA guideline for the Management of Heart Failure: A Report of the American College of Cardiology/American Heart Association Task Force on Clinical Practice Guidelines and the Heart Failure Society of America. Circulation. 2017 [Epub ahead of print], doi: 10.1161/CIR.0000000000000509, indexed in Pubmed: 28455343.

24. Delgado JF, Oliva F, Reinecke A. The inodilator levosimendan in repetitive doses in the treatment of advanced heart failure. Eur Heart J Suppl. 2017; 19(Suppl C): C8-C14, doi: 10.1093/eurheartj/sux004.

25. Kivikko M, Lehtonen L, Colucci WS. Sustained hemodynamic effects of intravenous levosimendan. Circulation. 2003; 107(1): 81-86, indexed in Pubmed: 12515747. 